\title{
PEACHES PHENOLOGY AND PRODUCTION SUBMITTED TO FOLIAR NITROGEN FERTILIZER AND CALCIUM NITRATE
}

\author{
FENOLOGIA E PRODUÇÃO DE PESSEGUEIROS SUBMETIDOS À APLICAÇÃO \\ DE FERTILIZANTE FOLIAR NITROGENADO E NITRATO DE CÁLCIO
}

\author{
Rafael Bibiano FERREIRA ${ }^{1}$; Sarita LEONEL ${ }^{1}$; Jackson Mirellys Azevêdo SOUZA ${ }^{\mathbf{1}}$; \\ Marcelo de Souza SILVA ${ }^{1}$; Rafael Augusto FERRAZ²; Rafaelly Calsavara MARTINS ${ }^{1}$; \\ Marcela Sant'Anna Cordeiro da SILVA ${ }^{3}$ \\ 1. Department of Horticulture, São Paulo State University (UNESP), School of Agriculture, Botucatu, SP, Brazil. \\ aprigio_bibiano@hotmail.com; 2. Federal Institute of Amazonas (IFAM), Campus Itacoatiara, Itacoatiara, AM, Brazil; 3. University of \\ São Paulo, Luiz de Queiroz College of Agriculture, Department of Crop Science, Piracicaba, SP, Brazil.
}

\begin{abstract}
Choosing cultivars that require less chilling temperatures to overcome dormancy is crucial, for example, peaches that grow in subtropical areas, which is not an appropriate climate for them. Thus, alternative techniques are necessary to induce sprouting. Yet there are not many available products in market, restricting options for fruit growers to a reduced number of chemical molecules, which are often harm the health to applicators. Therefore, this study aimed to assess phenological cycles and productive performance of three peach cultivars, submitted to foliar nitrogen fertilizer and calcium nitrate to induce sprouting. This study took place at Experimental Orchard of School of Agriculture (FCA, UNESP), Botucatu, state of São Paulo. Three peach cultivars were evaluated: 'Douradão', 'BRS Kampai' and 'BRS Rubimel' by applying four doses of foliar nitrogen fertilizer (FNF) at $0,1.25,2.50$ and $3.75 \%$; associated with $4 \%$ calcium nitrate. A $3 \times 4$ factorial arrangement ( 3 cultivars X 4 FNF doses) in a randomized block design was used, with 4 replicates and 2 plants per plot, totalizing 96 plants. Results indicated that FNF positively affected cultivars development, providing wider sprouting, flowering and fruit set; consequently, greater production. Then FNF became a good alternative to induce sprouting in peaches at mild winter temperatures. Moreover, 'BRS Rubimel' presented high sowing percentage associated with low flowering and fruit set percentages, that is, low production mainly caused by its lack of adaptability to studied region.
\end{abstract}

KEYWORDS: Erger. Prunus persica (L.) Batsch. Sprout induction. Overcoming dormancy.

\section{INTRODUCTION}

Peach tree (Prunus persica L. Batsch) belongs to the Rosaceae family. It originated in China and is classified as a temperate fruit that requires chilling temperature during winter to overcome dormancy (FERRAZ et al., 2015), to stimulate sprouting and flowering (WAGNER JÚNIOR et al., 2009).

Studies in crop genetic improvement programmes are leading to grow peaches in subtropical and tropical climate all over the world (SCARIOTTO et al., 2013). Due to genotypes development and selection that require low chilling temperatures to overcome dormancy, that is, enabling to grow in mild winter climate areas (WAGNER JÚNIOR et al., 2009).

Moreover, these growing regions present low chilling hours accumulation in winter (below $7.2^{\circ} \mathrm{C}$ ) during vegetative rest period, which can delay and increase flowering time, low flowering and budding percentage; consequently, yield reduction with non-uniform and low quality fruits (CITADIN et al., 2006). Thus different management practices are necessary to enable good plants development, for example, application of products to induce branches sprouting, allow more balanced and vigorous development.

Among main products present in market to stimulate sprouting, hydrogen cyanamide is known as the most effective (SEGANTINI et al., 2015), but its high toxicity have been restricted in many countries (LEONEL et al., 2014). Such restriction has stimulated the search for other compounds to induce sprouting in temperate fruits, such as potassium nitrates (ELSABAGH, 2014); calcium (NACHTIGALL; CAMELATTO, 1997); mineral oils (OLIVEIRA et al., 2008); and garlic extracts (OLIVEIRA et al., 2009).

In addition to these products, foliar nitrogen fertilizer (FNF) is a product composed by mono-and disaccharides, calcium, nitrogen and diterpenes. FNF enables cellular respiration of buds under adverse climatic conditions, since all released 
compounds reactivated metabolism of buds (VALAGRO, 2013). Several authors have reported FNF efficiency in promoting sprouting and flowering in some temperate fruits, such as kiwi (HERNÂNDEZ; CRAIG， 2011); blackberry (SEGANTINI et al., 2015); and apple (HAWERROTH et al., 2010).

Further studies are necessary to determine the best product doses in other temperate fruits to become a feasible option for fruit growers. This study aimed to evaluate phenological cycles and productive performance of peach cultivars, submitted to foliar nitrogen fertilizer and calcium nitrate to induce sprouting in subtropical climate of São Paulo state.

\section{MATERIAL AND METHODS}

\section{Experimental area and treatments description}

This study took place at Experimental Orchard of School of Agriculture (FCA, UNESP), in the city of Botucatu (22 $51^{\prime} 55^{\prime \prime} \mathrm{S} 48^{\circ} 27^{\prime} 22^{\prime \prime} \mathrm{W}$ and an altitude of 810), state of São Paulo. In this area, the climate is Cfa type, that is, hot temperate (mesothermal), with an average annual temperature of $20.3^{\circ} \mathrm{C}$ (CUNHA and MARTINS, 2009). Besides that soil was classified as Red Nitosol (EMBRAPA, 1999). Fertilizer recommendations were drawn based on soil tests and crop requirements (RAIJ et al., 2001).

Table 1. Soil macronutrients levels of the experimental area in the following years: 2015 and 2016.

\begin{tabular}{|c|c|c|c|c|c|c|c|c|c|c|c|}
\hline Sample & $\begin{array}{c}\mathrm{pH} \\
\mathrm{CaCl}_{2}\end{array}$ & $\begin{array}{l}\text { M.O. } \\
\text { g/dm }\end{array}$ & $\begin{array}{l}\text { Presina } \\
\mathrm{mg} / \mathrm{dm}^{3}\end{array}$ & $\mathrm{Al}^{3+}$ & $\mathrm{H}+\mathrm{Al}$ & $\mathrm{K}$ & $\begin{array}{r}\mathrm{Ca} \\
\mathrm{amol}\end{array}$ & $\begin{array}{l}\mathrm{Mg} \\
\mathrm{dm}^{3}\end{array}$ & SB & CTC & V\% \\
\hline \multicolumn{12}{|l|}{2015} \\
\hline $0-20$ & 5,2 & 23 & 25 & 0 & 31 & 2,9 & 18 & 15 & 35 & 66 & 53 \\
\hline $20-40$ & 5,5 & 22 & 89 & 0 & 26 & 3,2 & 23 & 15 & 41 & 67 & 61 \\
\hline \multicolumn{12}{|l|}{2016} \\
\hline $0-20$ & 5,4 & 24 & 28 & 0 & 30 & 3,0 & 35 & 13 & 51 & 81 & 63 \\
\hline $20-40$ & 5,2 & 24 & 20 & 0 & 37 & 2,2 & 32 & 14 & 48 & 85 & 56 \\
\hline
\end{tabular}

Source: Laboratory of Soil Fertility. DCS-FCA. 2015 and 2016.

Table 2. Soil micronutrients levels of the experimental area in the following years: 2015 and 2016.

\begin{tabular}{ccccccc}
\hline Sample & $\mathrm{B}$ & $\mathrm{Cu}$ & $\begin{array}{c}\mathrm{Fe} \\
\mathrm{mg} / \mathrm{dm}^{3}\end{array}$ & $\mathrm{Mn}$ & $\mathrm{Zn}$ \\
& & \multicolumn{7}{c}{} \\
\hline 2015 & 0,24 & 6,8 & 32 & 10,8 & 1,6 \\
\hline $0-20$ & 0,28 & 6,6 & 27 & 11,8 & 2,6 \\
$20-40$ & 0,30 & 6,5 & 36 & 11,9 & 3,8 \\
\hline 2016 & 0,26 & 6,9 & 32 & 12,7 & 3,6 \\
\hline $0-20$ & & & & & & \\
\hline
\end{tabular}

Source: Laboratory of Soil Fertility. DCS-FCA. 2015 and 2016.

Three peach cultivars: 'Douradão', 'BRS Kampai' and 'BRS Rubimel' were assessed in two crop cycles (2015 \& 2016), plants aged 4 and 5 years old, respectively. Moreover, the traditional "open vase" peach tree was used at spacing of $6.0 \times 4.0 \mathrm{~m}$, grafted on 'Okinawa' rootstock.

Seedlings were grown in Pelotas (RS) by Frutplan Mudas Ltda., and registered under 0099/2005 RENASEN (National Registry of Seeds and Seedlings). Centre for Temperate
Climate Agricultural Research donated all seedlings.

Therefore, treatments consisted of three peach cultivars and four doses of foliar nitrogen fertilizer (FNF) at $0,1.25,2.50$ and $3.75 \%$ in association with $4 \%$ calcium nitrate $(4 \% \mathrm{CN})$; the latter was added in all treatments. Fruiting pruning was made on July 15 in both crop cycles. After pruning, FNF Erger ${ }^{\circledR}$ was immediately applied, such product is consisted of mono-and polysaccharides, 
$15 \%$ total nitrogen and $6.5 \%$ calcium oxide; this fertilizer is available as soluble concentrate and presents low toxicity.

\section{Morphological and Productive Analysis}

Eight mixed branches of $25 \mathrm{~cm}$ long were randomly selected in each plant, which were distributed around the canopy perimeter in trees medial portion. Before evaluations, number of vegetative and flower buds were counted in selected branches. Subsequently, number of vegetative buds (green tip stage) and open flowers were measured in selected branches every three days. At the end of flowering and beginning of fruits development, fruiting percentage was determined for each of selected branch. At harvesting, fruit number, production and accumulated yield were determined in each treatment during both crop cycles.

Analyzes were made according to the following methodologies: relationship between flower bud/vegetative bud $(\mathrm{Fb} / \mathrm{Vb})$ : determined by the ratio between number of flower bud and number of vegetative bud in each evaluated branch; flowering percentage: by counting the total flower number in each branch throughout productive cycle, and determined by the following formula: \% flowering $=\left(\mathrm{n}^{\mathrm{o}}\right.$ open flower $/ \mathrm{n}^{\mathrm{o}}$ flower bud $) \times 100$; sprouting percentage: by counting the total sprouted bud number in each branch throughout productive cycle, and determined by the following formula: $\%$ sprouted bud $=\left(\mathrm{n}^{\circ}\right.$ sprouting $/ \mathrm{n}^{\circ}$ vegetative bud $) \mathrm{x}$ 100; fruit set percentage, evaluated at 20 days after full bloom (i.e. thinning period), and determined by the following formula: $\%$ set of fruits $=\left(\mathrm{n}^{\mathrm{o}}\right.$ fruit set $/ \mathrm{n}^{\circ}$ flower bud) $\mathrm{x} 100$; accumulated production, in $\mathrm{kg}$ plant $^{-1}$, determined by total fruit number and fruit fresh mass, harvested per plant during both crop cycles; and accumulated yield, expressed as $\mathrm{tha}^{-1}$ at a planting density of 417 plants $\mathrm{ha}^{-1}$. Accumulated data was considered during calculation of productive traits, that is, fruit number, production and yield.

\section{Experimental design and data analysis}

A $3 \times 4$ factorial arrangement ( 3 cultivars $\mathrm{X} 4$ FNF doses $+\left[\begin{array}{ll}4 \% & \mathrm{CN}\end{array}\right]$ ) in a randomized block design was used, with 4 replicates and 2 useful plants per plot; thus 12 treatments with 96 plants at the end.

Data were submitted to analysis of variance, when significant, Tukey test, at $1 \%$ and $5 \%$, was performed for comparison of cultivars, and regression analysis for FNF doses. All analyzes were performed using SISVAR ${ }^{\circledR}$ software (FERREIRA, 2011). Data referring to sprouting, flowering, fruit set percentages were transformed into arc sine formula $(\operatorname{root}(\mathrm{x} / 100))$.

\section{RESULTS AND DISCUSSION}

\section{Number of vegetative bud (Vg), flower bud (Fb), and $\mathrm{Fb} / \mathrm{Vb}$ ratio}

Results showed no statistically significant interaction between cultivars and FNF doses in relation to number of vegetative buds, flower buds and $\mathrm{Fb} / \mathrm{Vb}$ ratio. But a significant effect of cultivars on those traits occurred in 2015. While doses presented an effect on number of vegetative buds in 2016, that cultivars showed a response on flower bud number, while $\mathrm{Fb} / \mathrm{Vb}$ ratio presented an isolated effect of both factors.

Considering that 2015 was the first evaluation cycle, we were unable to observe product interference in branch formation of three evaluated cultivar. Yet plant formation and growth happened when no treatments were made, that is, before conducting experiment, since flowering and production appear in previous growth cycle; showing that only cultivars presented differences during first evaluated cycle.

During 2015, the highest average number of vegetative buds were found in 'BRS Rubimel' (10.98 buds) and 'BRS Kampai' (11.29 buds); while 'Douradão' presented 8.5 buds (Table 3 ). Regarding to the flower bud number in 2015, the highest averages were found in 'BRS Kampai' (14.43 buds), compared to 'BRS Rubimel' (9.88 buds) and 'Douradão' (11.45 buds) (Table 3). In 2016, the highest values were found in 'Douradão' (14.99 buds) and 'BRS Kampai' (14.30 buds).

In addition to flowering and cultivar production, flower bud formation is an important parameter to select adapted materials over a wide range of climate condition. Also, cultivar is taken into account during crop recommendation in different growing areas (PEREIRA; MAYER, 2008). The main factors related to flower bud formation are those linked to internal plant conditions, such as age, hormonal balance, nutrition, carbon:nitrogen ratio, management practices (e.g. pruning) and weather conditions (CHILDERS, 1983), as photoperiod.

'BRS Kampai' and 'Douradão' obtained the highest ratio between buds $(\mathrm{Fb} / \mathrm{Vb})$ in both cycles. In 2015, both cultivars did not differ significantly with the following ratio 1.31 and 1.49 , respectively. In 2016, 'Douradão' presented higher ratio (1.66) than other treatments, while 'BRS Kampai' had an intermediate outcome (1.43) (Table 3). 
Table 3. Number of vegetative buds, flower buds and $\mathrm{Fb} / \mathrm{Vb}$ ratio for peach cultivars submitted to foliar nitrogen fertilizer and calcium nitrate during 2015 and 2016 cycles.

\begin{tabular}{ccccccc}
\hline \multirow{2}{*}{ Cultivar } & \multicolumn{3}{c}{2015} & \multicolumn{3}{c}{2016} \\
\cline { 2 - 7 } & $\mathrm{Vb}$ & $\mathrm{Fb}$ & $\mathrm{Fb} / \mathrm{Vb}$ & $\mathrm{Vb}$ & $\mathrm{Fb}$ & $\mathrm{Fb} / \mathrm{Vb}$ \\
\hline Douradão & $8.5 \mathrm{~b}$ & $11.45 \mathrm{~b}$ & $1.49 \mathrm{a}$ & $10.01 \mathrm{a}$ & $14.99 \mathrm{a}$ & $1.66 \mathrm{a}$ \\
BRS Kampai & $11.29 \mathrm{a}$ & $14.43 \mathrm{a}$ & $1.31 \mathrm{a}$ & $10.42 \mathrm{a}$ & $14.30 \mathrm{a}$ & $1.43 \mathrm{~b}$ \\
BRS Rubimel & $10.98 \mathrm{a}$ & $9.88 \mathrm{c}$ & $0.96 \mathrm{~b}$ & $10.37 \mathrm{a}$ & $10.87 \mathrm{~b}$ & $1.12 \mathrm{c}$ \\
\hline Mean & 10.26 & 11.92 & 1.25 & 10.28 & 13.4 & 1.40 \\
DMS & 0.91 & 1.69 & 0.18 & 1.09 & 1.39 & 0.12 \\
\hline
\end{tabular}

Means followed by the same letter in column do not differ significantly by Tukey test at $1 \%$ significance.

'BRS Rubimel' presented a high number of vegetative buds and a low number of flower buds in both productive cycles; therefore, a reduction in $\mathrm{Fb}$ $/ \mathrm{Vb}$ ratio, such characteristic enabled vegetative development of plants in detriment of flowering and fruit formation; consequently, damaging their productive performance.

In addition to differences between cultivars, the relationship between peach buds can also be influenced by green pruning, branch type, evaluation cycle (NIENOW, 1997) and region's climate. In peach tree branches, the ideal $\mathrm{Fb} / \mathrm{Vb}$ ratio is close to $2: 1$ (i.e. two flower buds for each vegetative bud), which leads to a balanced growth between plants vegetative and reproductive structures (PENSO, 2016). Therefore, 'Douradão' and 'BRS Kampai' were the ones that presented branches closer to the ideal ratio, demonstrating their wider adaptability in Botucatu.

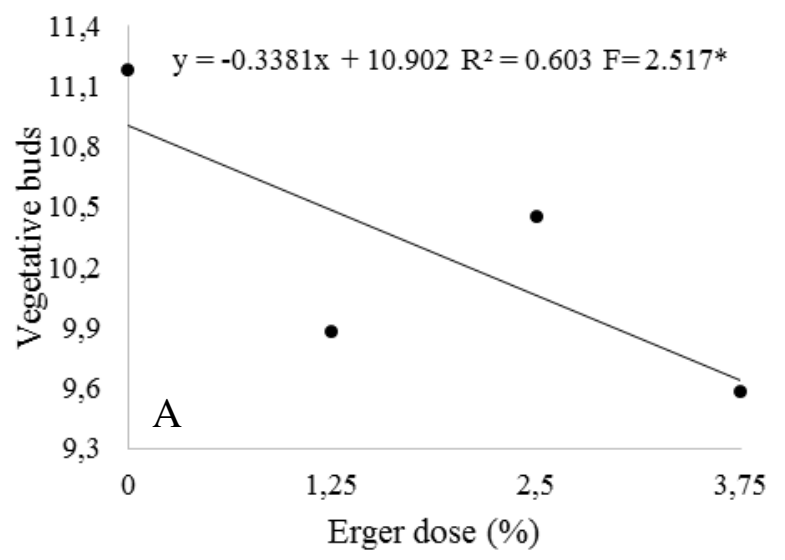

By increasing FNF doses, the number of vegetative buds decreased, showing a negative linear behaviour of doses on vegetative bud formation in 2016 cycle (Figure 1A). In peach tree branches, the presence of vegetative buds is directly linked to the formation of new branches and leaves, which guarantees not only plant photosynthetic activity, but also quality fruits production (PEREIRA, MAYER, 2008). In general, 30 to 35 leaves are required to produce a fruit (RASEIRA et al., 1998). Moreover, new shoots that form along branches will extend productive maintenance to the next cycle.

In 2016 cycle, data referring to FNF doses on $\mathrm{Fb} / \mathrm{Vb}$ ratio showed a positive linear behaviour, with a difference of 0.19 between $0.00 \%$ and $3.75 \%$ FNF (Figure 1B). Therefore, product did not influence flower buds formation, since there was a reduction in number of vegetative buds by increasing FNF dose (Figure 1).

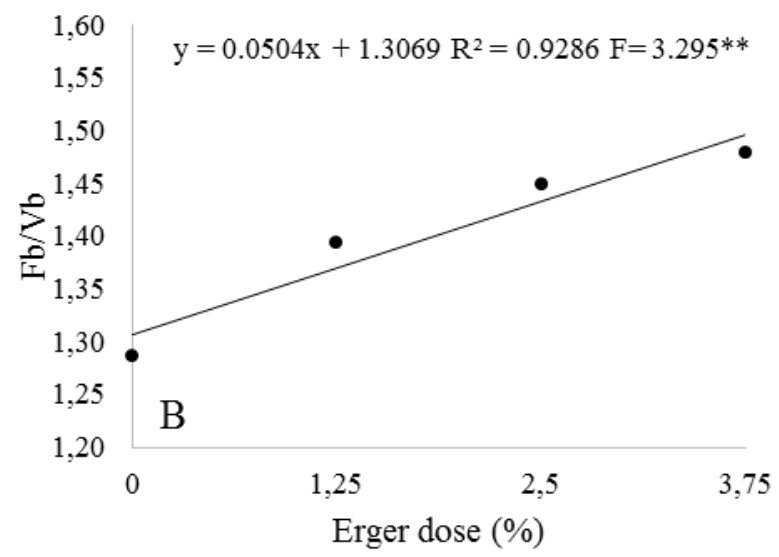

Figure 1. Number of vegetative buds $(\mathrm{A})$ and $\mathrm{Fb} / \mathrm{Vb}$ ratio $(\mathrm{B})$ in peach tree branches submitted to foliar nitrogen fertilizer and calcium nitrate during 2016 productive cycle.

\section{Percentage of sprouted bud, flowering and fruit set}

There was no significant interaction in the percentages of sprouted buds, flowering and fruit set between cultivars and FNF doses in both cycles. But there were isolated effects of cultivars and FNF doses.

For sprouted buds, the highest percentage was found in 'BRS Kampai' (74.62\%), compared to 'Douradão' (64.20\%) and 'BRS Rubimel' (64.94\%) 
in 2015 (Table 4). Therefore, mixed branches presented high rates of sprouted buds, which can provide a high number of productive branches to next cycle, thus maintaining plants production. In the second crop cycle, the three cultivars presented low sprouted bud percentages in their branches (i.e. below $40 \%$ ); then showing that alternative products are needed to induce sprouting in plants after pruning in Botucatu.

'Douradão' presented the highest percentages of flowering and fruit set during both crop cycles, with mean values of $48.46 \%$ and $49.48 \%$ open flowers and $36.21 \%$ and $40.29 \%$ fruits set in 2015 and 2016, respectively (Table 4). Corroborating with the mean of $35.68 \%$ fruit set found in pruned 'Douradão' treated with $0.5 \%$ hydrogen cyanamide and $1 \%$ mineral oil in São
Manuel by Segantini et al. (2014). However, higher means were found in 'Aurora-1' (50.97\%) and 'Golden-1' (75.46\%) by the same authors.

Regarding to flowering, 'BRS Kampai' and 'BRS Rubimel' did not differ significantly from crop cycles, with a mean of $27.78 \%$ and $29.38 \%$ in 2015; besides $27.91 \%$ and $25.18 \%$ in 2016, respectively (Table 4). But these results changed when fruit set was analyzed, since 'BRS Rubimel' was significantly lower than 'BRS Kampai'; thus indicating the lowest number of open flowers that were converted into fruits in that cultivar. The main factors that influenced fruit retention in peach plants are related to their nutritional status, genetic traits and environmental conditions (NAVA et al., 2009), suggesting that 'BRS Rubimel' presented low adaptability in Botucatu.

Table 4. Percentage of sprouted bud, flowering and fruit set of peach cultivars submitted to foliar nitrogen fertilizer and calcium nitrate during 2015 and 2016 cycles.

\begin{tabular}{ccccccc}
\hline \multirow{2}{*}{ Cultivar } & \multicolumn{2}{c}{ Sprouted bud (\%) } & \multicolumn{2}{c}{ Flowering (\%) } & \multicolumn{2}{c}{ Fruit set (\%) } \\
\cline { 2 - 7 } & \multicolumn{2}{c}{ Year } & \multicolumn{2}{c}{ Year } & \multicolumn{2}{c}{ Year } \\
\cline { 2 - 7 } & 2015 & 2016 & 2015 & 2016 & 2015 & 2016 \\
\hline Douradão & $64.20 \mathrm{~b}$ & $21.15 \mathrm{c}$ & $48.46 \mathrm{a}$ & $49.68 \mathrm{a}$ & $36.31 \mathrm{a}$ & $40.29 \mathrm{a}$ \\
BRS Kampai & $74.62 \mathrm{a}$ & $28.42 \mathrm{~b}$ & $37.78 \mathrm{~b}$ & $31.37 \mathrm{~b}$ & $27.91 \mathrm{~b}$ & $23.37 \mathrm{~b}$ \\
BRS Rubimel & $64.94 \mathrm{~b}$ & $38.04 \mathrm{a}$ & $29.38 \mathrm{~b}$ & $12.49 \mathrm{c}$ & $25.18 \mathrm{~b}$ & $9.55 \mathrm{c}$ \\
\hline Mean & 67.92 & 29.2 & 38.54 & 31.18 & 28.8 & 18.57 \\
DMS & 7.93 & 4.99 & 8.03 & 8.95 & 7.09 & 6.78 \\
\hline
\end{tabular}

Means followed by the same letter in column do not differ significantly by Tukey test at $1 \%$ significance.

The mean percentage of sprouted bud presented a quadratic growth in function of FNF doses in 2015. The maximum value of the function showed $82.8 \%$ sprouted bud at $2.5 \%$ FNF (Figure 2A). In 2016, there was a linear increase in the percentage of sprouted bud by increasing FNF doses; and the maximum value was of $30.31 \%$ at $3.75 \%$ FNF (Figure 2B).

Regarding to sprouted bud, the positive outcome of FNF was also found in Tupy blackberry (92.4\%) at 6.8\% FNF in São Manuel by Segantini et al. (2015). Moreover, other positive results were found in 'Gala' (52.1\%) and 'Fuji Suprema' $(61.5 \%)$ apples by applying 3\% FNF and 3\% CN, compared to control 'Gala' (12.8\%) and 'Fuji Suprema' (30.3\%) by Hawerroth et al. (2010); thus an effective sprout stimulant product for temperate fruits.

Studies on apple trees indicate that the use of compounds to overcome dormancy, such as hydrogen cyanamide, potassium nitrate and mineral oil, enhanced levels of soluble nitrogen and total polyamines in plant buds. With regard to those metabolites, sprouting and fruiting increased in branches (EL-YAZAL; RADY, 2012). Besides that polyamines are nitrogen compounds (TASSONI et al., 2008) and play a role in flower sexual differentiation and opening (FAGAN, 2015). Due to the high nitrogen levels present in FNF, product action may increase their compounds levels in plant bud; thus enhancing sprouting in peach tree branches.

By considering FNF doses, a quadratic regression model significantly increased flowering percentage, as the maximum value of the function was of $43.7 \%$ open flowers at $2.2 \%$ (Figure 2C) in 2015. But there was a linear increase in flowering by enhancing FNF doses, showing a difference of $13.06 \%$ open flowers between $0.00 \%$ and $3.75 \%$ of product dose in 2016 (Figure 2D). 

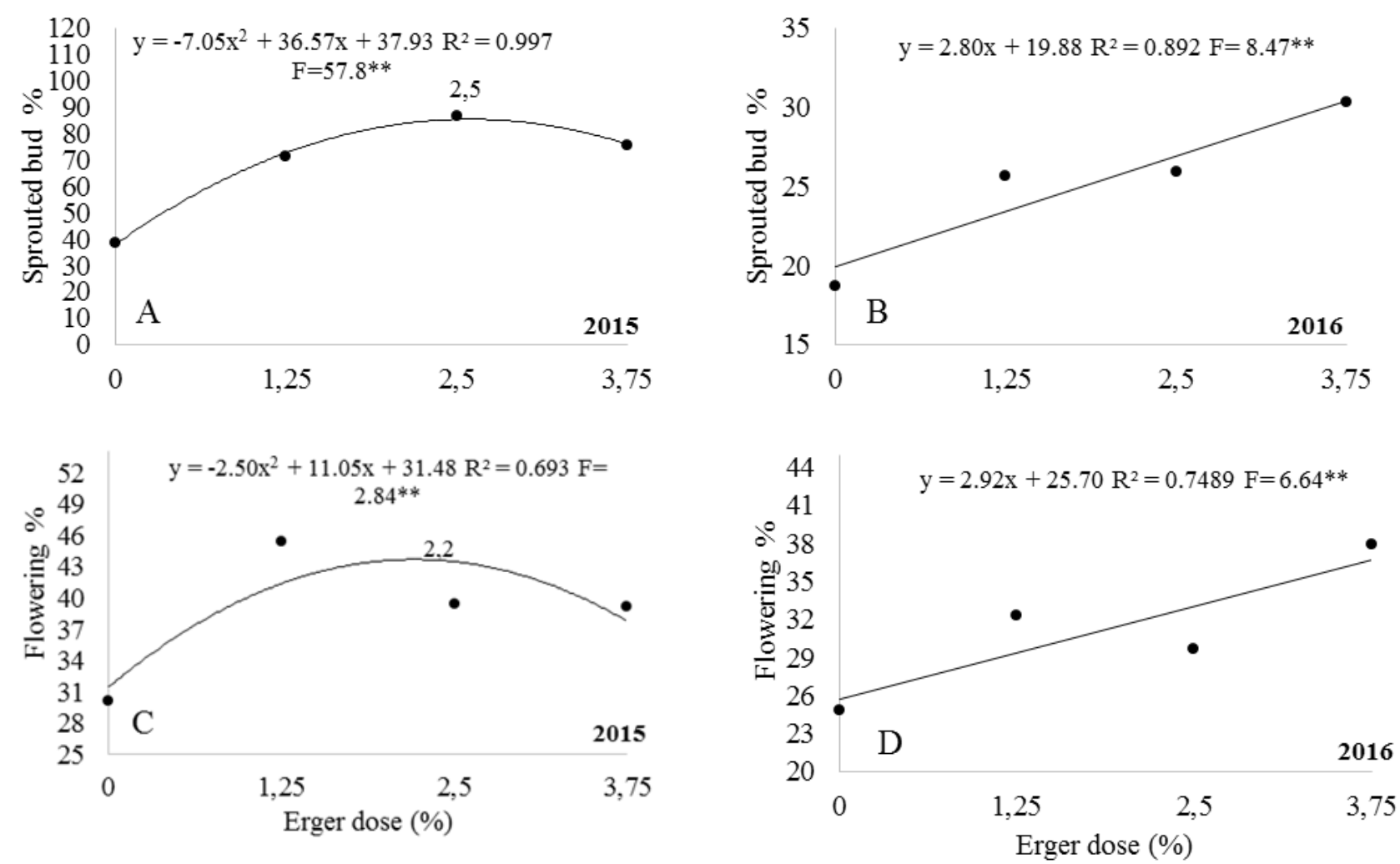

Figure 2. Percentage of sprouted bud (A, B) and flowering (C, D) in peach tree branches submitted to foliar nitrogen fertilizer and calcium nitrate during 2015 and 2016 cycles.

Furthermore, different nitrogen forms in FNF can cause respiratory stress in the plant buds (SEGANTINI et al., 2015), which not only induces sprouting of vegetative buds, but also increases flower opening; therefore, a positive effect on plants productive traits.

By assessing nitrogen compounds and carbohydrate content in peach tree branches due to chilling accumulation during dormancy, GonzalezRossia et al. (2008) observed a wider percentage of flowering (65.9\%), when plants accumulated 500 chilling hours at temperature below $3^{\circ} \mathrm{C}$. In addition, the highest flowering intensity was associated with high concentrations of ammonium $\left(\mathrm{NH}_{4}\right)$ and glucose in branches, since these compounds mobilization and cycling are important for overcoming dormancy, as they enable flower initiation and development.

Sprouting involves translocation and reassimilation of large amounts of storage compounds, according to Cantón et al. (2005). Within this process, storage proteins are converted into amino acids, which are hydrolyzed in high amounts of $\mathrm{NH}_{4}$ and reassimilated to form new compounds of nitrogen that are necessary for growth.

In cold-failure conditions, hydrolysis and conversion of plant reserves are insufficient, compromising sprouting and flowering
(GONZALEZ-ROSSIA et al., 2008); then the beneficial effects of FNF, which directly releases essential compounds to induce bud sprouting in both vegetative and reproductive structures, such as monosaccharide, disaccharides, calcium, diterpenes and nitrogen, as urea, ammonia and nitric forms.

Regarding to fruit set and FNF doses, a quadratic growth was reported, as the maximum value of the function was of $33.3 \%$ at estimated dose of $2.1 \%$ in 2015 (Figure 3A). Fruit set percentage linearly increased by enhancing FNF dose up to $3.75 \%$, where $31.39 \%$ fruit set was observed (Figure 3B).

These results resemble those found in 'Douradão', pruned in July and submitted to $0.6 \%$ hydrogen cyanamide and $1 \%$ mineral oil, as $38.48 \%$ fruit set was reported in branches length of $25 \mathrm{~cm}$, not differing from 'BRS Kampai' (27.68\%) in Botucatu, according to Ferraz et al. (2015).

A low effective fruiting was observed in 'Gala' apple trees by Hawerroth et al. (2010), due to high doses of FNF (7\%) and $\mathrm{CN}$ (7\%), as leaf rapidly developed and competed with flower development, thus reducing effective fruits in branches (PETRI et al., 2005). The same behaviour could also be observed in this study during the first crop cycle, when flowering and fruiting percentage decreased by enhancing FNF above $2.2 \%$. 

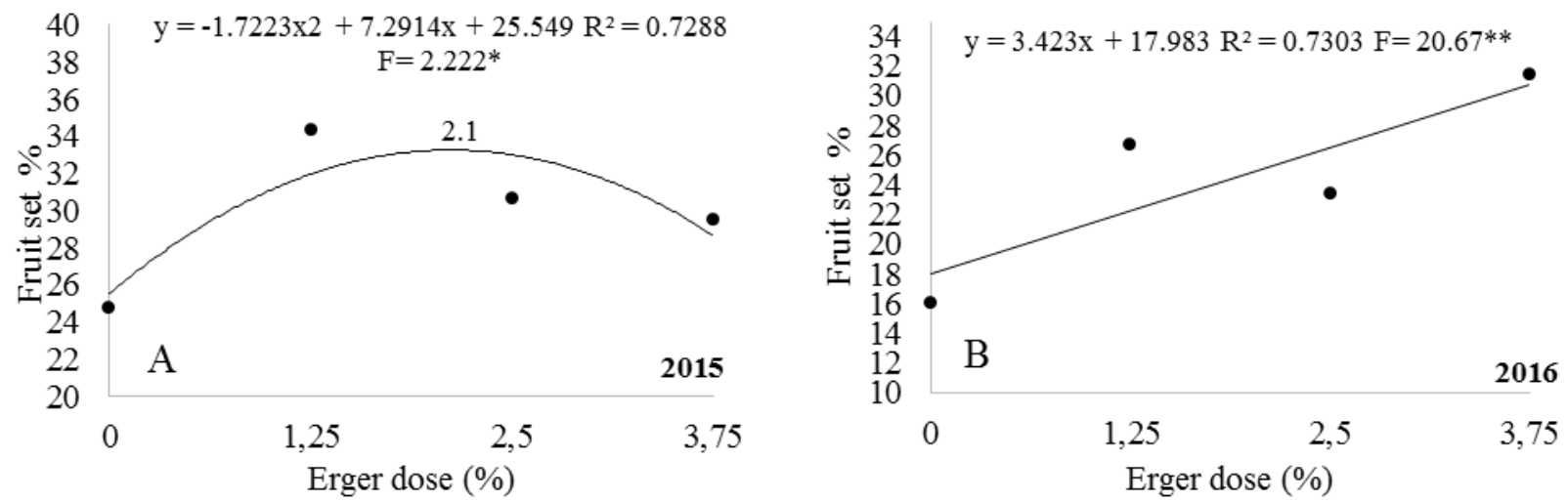

Figure 3. Percentage of fruit set in peach tree branches submitted to foliar nitrogen fertilizer and calcium nitrate during 2015 and 2016 cycles.

The use of compounds to stimulate sprouting may increase competition between plants vegetative and reproductive structures (EREZ, 2000). The beginning of sprouting in vegetative and reproductive buds of temperate fruits depends on reserves stored in plant during previous cycle (FAUST, 2000). Besides FNF tends to accelerate sprouting, which may have compromised the availability of reserves during flower opening; thus, hindering flowering and fruit formation at higher doses.

In the second evaluation cycle, sprouting percentage was relatively low, which softened metabolites competition between vegetative and reproductive structures; thus favouring wider flowering and fruit set by increasing FNF doses.

\section{Fruit number, Production and Yield}

With regards to fruit number, production and yield, there was no significant interaction between FNF doses and cultivars. However, there were isolated effects of cultivars and FNF doses. 'Douradão' and 'BRS Kampai' obtained the highest accumulated productive indexes during both cycles. 'Douradão' produced 184.25 fruits $\mathrm{pl}^{-1}$, then an accumulated yield of $7680.58 \mathrm{~kg} \mathrm{ha}^{-1}$ (Table 5). 'BRS Kampai' had an accumulated productive index of 170.21 fruits $\mathrm{pl}^{-1}$, with accumulated yield of $7250.34 \mathrm{~kg} \mathrm{ha}^{-1}$.

'BRS Rubimel' obtained the lowest accumulated number of fruits among cultivars. Therefore, the lowest production and yield values may have occurred by their low percentages of flowering and fruit set during both cycles, indicating their low adaptability to Botucatu conditions (Table 4).

Table 5. Number of fruits, production and yield of peach cultivars submitted to foliar nitrogen fertilizer and calcium nitrate during the 2015 and 2016 cycles.

\begin{tabular}{cccc}
\hline Cultivar & $\mathrm{N}^{\circ}$ Frutos $\mathrm{l}^{-1}$ & Produção $\mathrm{Kg} \mathrm{pl}^{-1}$ & Produtividade Kg ha $^{-1}$ \\
\hline Douradao & $184.25 \mathrm{a}$ & $18.42 \mathrm{a}$ & $7680.58 \mathrm{a}$ \\
BRS Kampai & $170.21 \mathrm{a}$ & $17.39 \mathrm{a}$ & $7250.34 \mathrm{a}$ \\
BRS Rubimel & $125.65 \mathrm{~b}$ & $12.81 \mathrm{~b}$ & $5342.75 \mathrm{~b}$ \\
\hline Média & 160.04 & 16.21 & 6757.89 \\
DMS & 36.75 & 4.09 & $1,707.83$ \\
\hline
\end{tabular}

Means followed by the same letter in column do not differ significantly by Tukey test at $1 \%$ significance.

Under São Manuel conditions, Segantini et al. (2014) found in 'Douradão' $2.39 \mathrm{t} \mathrm{ha}^{-1}$ (2009/2010) and 9.11 $\mathrm{t} \mathrm{ha}^{-1}(2010 / 2011)$. In Botucatu, Ferraz et al. (2015) obtained in 'Douradão', 'BRS Kampai' and 'BRS Rubimel', pruned in July and submitted to $0.6 \%$ hydrogen cyanamide $+1 \%$ mineral oil, yields of $1.18,2.07$ and $2.43 \mathrm{t} \mathrm{ha}^{-1}$, respectively. Such differences are due to plant age and annual climatic conditions.
Data referring to the isolated effect of FNF doses on fruit number, production $\left(\mathrm{kg} \mathrm{pl}^{-1}\right)$ and yield $\left(\mathrm{kg} \mathrm{h} \mathrm{h}^{-1}\right)$ were adjusted to positive quadratic regression model, with a maximum value of the function at the estimated doses of $2.2 \%$ (fruits $\mathrm{pl}^{-1}$ ) and $2.3 \%$ (production and yield), which would provide 192 fruits $\mathrm{pl}^{-1}$, a production of $19 \mathrm{~kg} \mathrm{pl}^{-1}$ and a yield of $8044.5 \mathrm{~kg} \mathrm{ha}^{-1}$ in both cycles (Figures 4A, 4B and 4C). 

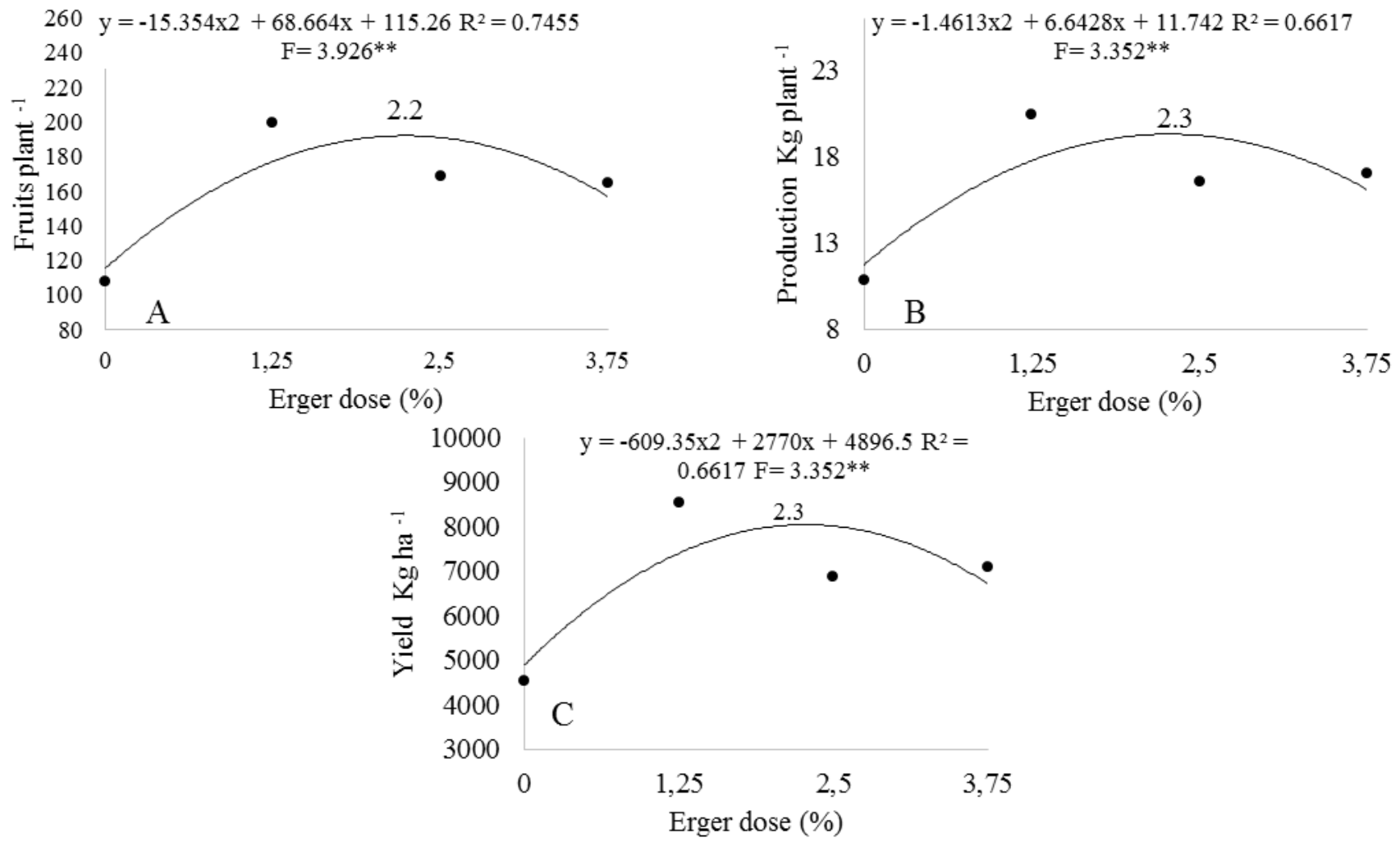

Figure 4. Number of fruits per plant (A), production (B) and yield (C) in peach cultivars submitted to foliar nitrogen fertilizer and calcium nitrate during 2015 and 2016 cycles.

In response to product application to overcome dormancy, the highest fruit number was also verified in 'Roxo de Valinhos' fig tree at $6 \%$ garlic extract, as produced more fruits in comparison to the other dosages (Leonel et al.,2015). In 'Tupy' blackberry, Segantini et al. (2015) recommend an estimated dose of 5.4\% FNF, since it provided the highest fruit production (521 fruits plant $^{-1}$ ), but doses higher than that reduced plant production. For 'Imperial Gala' apple, it is recommended to use doses below 7\% Erger $^{\circledR}$, as fruit reduction can happen above that value (HAWERROTH et al., 2010), besides increasing competition between vegetative and reproductive structures.

With regarding to FNF doses, different temperate fruits were mentioned; similarities are found though, as there was an increase in productive variables. However, all temperature fruits require an ideal dose, since higher doses can compromise both plant development and production.

\section{CONCLUSIONS}

'BRS Rubimel' presented the highest sprouting percentage, besides low levels of flowering and fruit set, which negatively affect production; thus indicating low adaptability to weather conditions (Cfa) of Botucatu, state of São Paulo.

'Douradão' and 'BRS Kampai' had good phenological and productive performance, being a good option for growing peaches in Botucatu.

For the climatic conditions of Botucatu, FNF can be used as an alternative to induce sprouting in peach trees, as provided wider sprouting, flowering and fruit production.

\section{ACKNOWLEDGMENT}

The authors would thank to National Council for Scientific and Technological Development $(\mathrm{CNPq})$ and the Coordination for the Improvement of Higher Education Personnel (CAPES) to scholarship granted for the studies.

To the VALAGRO company, especially to Mr. Vitor Hugo Artigiani Filho, for supporting me during the experiment execution. 
RESUMO: A escolha de cultivares mais adaptados, com menor exigência em acúmulo de horas de frio para superação da dormência, é fundamental para o cultivo do pessegueiro em regiões subtropicais. Uma vez que estas regiões não possuem condições ideais para o cultivo do pessegueiro, torna-se necessário a utilização de técnicas alternativas, como a aplicação de indutores de brotação. Entretanto, no mercado ainda existem poucos produtos disponíveis para esta finalidade, restringindo as opções do fruticultor a um número reduzido de moléculas químicas, que muitas vezes apresentam elevada toxicidade ao aplicador. Dentro deste contexto, objetivou-se com o presente trabalho avaliar os ciclos fenológicos e o desempenho produtivo de três cultivares de pessegueiro, submetidos à aplicação de fertilizante foliar nitrogenado e nitrato de cálcio para a indução da brotação das plantas. O trabalho foi realizado no pomar experimental da Faculdade de Ciências Agronômicas da Universidade Estadual Paulista, campus Botucatu, SP. Foram avaliados os cultivares de pessegueiro Douradão, BRS Kampai e BRS Rubimel e quatro doses de fertilizante foliar nitrogenado (FFN): 0; 1,25; 2,50 e $3,75 \%$, associadas a $4 \%$ de nitrato de cálcio. O delineamento experimental foi em blocos ao acaso, com 12 tratamentos, 4 repetições e 2 plantas por parcela, totalizando 96 plantas, em esquema fatorial, compreendendo 3 cultivares e 4 doses de FFN. O FFN afetou positivamente o desenvolvimento dos cultivares, proporcionando maior brotação, florescimento e fixação de frutos e, consequentemente, maior produção, configurando como boa alternativa para a indução de brotação de pessegueiros em regiões de inverno ameno. O cultivar BRS Rubimel apresentou elevado percentual de brotação associado a baixos percentuais de florescimento e fixação de frutos, o que refletiu em menor produção, evidenciando sua menor adaptabilidade à região de Botucatu - SP. dormência.

PALAVRAS-CHAVE: Erger. Prunus persica (L.) Batsch. Indução a brotação. Superação da

\section{REFERENCES}

CANTÓN, F. R.; SUÁREZ, M. F.; CANOVAS, F. Molecular aspects of nitrogen mobilization and recycling in trees. Photosynthesis Research, v. 83, p. 265-278, 2005. https://doi.org/10.1007/s11120-004-9366-9

CHILDERS, N. F. Modern fruit science. 8. ed. New Jersey: Horticultural Publications, 1983. 912 p.

CITADIN, F. BASSANI, M.H.; DANNER, M.A.; MAZARO, S.M.; GOUVÊA, A. Uso de cianamida hidrogenada e óleo mineral na floração, brotação e produção do pessegueiro "Chiripá". Revista Brasileira de Fruticultura, Jaboticabal - SP, v. 28, n. 1, p. 32-35, 2006. https://doi.org/10.1590/s0100-29452006000100012

CUNHA, A.R.; MARTINS, D. Classificação climática para os municípios de Botucatu e São Manuel, SP. Irriga, Botucatu, v. 14, n.1, p. 1-11, 2009. https://doi.org/10.15809/irriga.2009v14n1p1-11

ELSABAGH, A. S. Influences of potassium nitrate, gibberellin and benzyl adenine on bud break, fruit set and branch induction of almond trees. Acta Horticulturae, v. 1028, p. 359-366, 2014.

https://doi.org/10.17660/actahortic.2014.1028.58

EL-YAZAL, M. A. S.; RADY, M. M. Changes in nitrogen and polyamines during breaking bud dormancy in "Anna" apple trees with foliar application of some compounds. Scientia Horticulturae, v. 136, p. 75-80, 2012. https://doi.org/10.1016/j.scienta.2012.01.001

EMBRAPA. Centro Nacional de Pesquisa de Solos. Sistema Brasileiro de classificação de solos. Rio de Janeiro, 1999. 412 p. https://doi.org/10.17771/pucrio.acad.17520

EREZ, A. Bud dormancy: phenomenon, problems and solutions in the tropics and subtropics. In: EREZ, A. Temperate fruit crops in warm climates. Boston, London: Kluwer Academic Publishers, 2000. p.17-48. https://doi.org/10.1007/978-94-017-3215-4_2

FAGAN, E. B.; ONO, E. O.; RODRIGUES, J. D.; CHALFUN JÚNIOR, A.; DOURADO NETO, D. Fisiologia Vegetal: Reguladores Vegetais. São Paulo: Editora Andrei, 2015. 300 p. 
FAUST, M. Physiological considerations for growing temperate-zone fruit crops in warm climates. In.:

Temperate fruits crop in warm climates. Boston, London: Kluwer Academic Publishers, 2000. p.305-342. https://doi.org/10.1007/978-94-017-3215-4_7

FERRAZ, R. A.; LEONEL, S.; SEGANTINI, D. M.; Tecchio, M.A.; ANTUNES, L. E. C. Yield and crop cycle time of peaches cultivated in subtropical climates and subjected to different pruning times. Semina. Ciências Agrárias (Impresso), v. 36, p. 4099-4106, 2015. https://doi.org/10.5433/1679-0359.2015v36n6sup2p4099

FERREIRA, D. F. Sisvar: a computer statistical analysis system. Ciência e Agrotecnologia (UFLA), v. 35, n.6, p. 1039-1042,2011. https://doi.org/10.1590/s1413-70542011000600001

GONZÁLEZ-ROSSIA, D.; REIG, C.; DOVIS, V.; GARIGLIO, N.; AGUSTÍ, M. Changes on carbohydrates and nitrogen content in the bark tissues induced by artificial chilling and its relationship with dormancy bud break in Prunus sp. Scientia Horticulturae, v. 118, p. 275-28, 2008.

https://doi.org/10.1016/j.scienta.2008.06.011

HAWERROTH, F. J.; PETRI, J. L.; LEITE, G. B.; HERTER, F. G. Brotação de gemas em macieiras 'Imperial Gala' e 'Fuji Suprema' pelo uso de Erger ${ }^{\circledR}$ e nitrato de cálcio. Revista Brasileira de Fruticultura, v. 32, n.2, p. 258-271, 2010. https://doi.org/10.1590/s0100-29452010005000074

HERNÁNDEZ, G.; CRAIG, R. L. Effects of alternatives to hydrogen cyanamide on commercial kiwifruit production. Acta Horticulturae, v. 913, p. 357-363, 2011. https://doi.org/10.17660/actahortic.2011.913.47

LEONEL, S.; LEONEL, M.; TECCHIO, M. A.; Fruit quality in the peach and nectarine with application of hydrogenated cyanamide and mineral oil. Revista Ciência Agronômica, v. 45, n. 3, p. 581-587, jul-set, 2014. https://doi.org/10.1590/s1806-66902014000300020

LEONEL, S.; TECCHIO, M. A.; CÓSER, G. M. A. G. Dormancy Breaking of the Fig Tree with Hydrogen Cyanamide and Garlic Extrate. British Journal of Applied Science \& Technology, v. 10, n. 1, p. 1 - 10, 2015. https://doi.org/10.9734/bjast/2015/18194

NACHTIGALL, G.R.; CAMELATTO, D. Efeito da mistura de nitrato de cálcio com thidiazuron, cinamida hidrogenada e óleo mineral na superação da dormência de macieiras (Malus domestica, Borkh.) cv. Gala. Revista Brasileira de Fruticultura, Cruz das Almas, v. 19, n. 3, p. 275-282, 1997. https://doi.org/10.1590/s0100-29452011005000054

NAVA, G. A.; DALMAGO, G. A.; BERGAMASCHI, H.; MARODIN, G. A. B. Fenologia e produção de pessegueiros "Granada" com aplicação de cianamida hidrogenada e boro. Revista Brasileira de Fruticultura, v. 31, n. 2, p. 297-304, 2009. https://doi.org/10.1590/s0100-29452009000200003

NIENOW, A.A. Comportamento morfológico, fenológico e produtivo de cultivares de pessegueiro (Prunus persica (L.) Batsch), submetidos à poda de renovação após a colheita, na região de JaboticabalSP. 1997. 171f. Tese (Doutorado em Agronomia) - Faculdade de Ciências Agrárias e Veterinárias, Universidade Estadual Paulista, Jaboticabal, 1997. https://doi.org/10.17138/tgft(2)133-135

OLIVEIRA, O. R.; PERESSUTI, R. A.; SKALITZ, R.; ANTUNES, M. C.; BIASI, L. A.; ZANETTE, F. quebra de dormência de pereira 'hosui' com uso de óleo mineral em dois tipos de condução. Revista Brasileira Fruticultura, Jaboticabal - SP, v. 30, n. 2, p. 409-413, 2008. https://doi.org/10.1590/s0100-

29452008000200024

OLIVEIRA, O. R.; LIPSKI, B.; SILVA, E. D. B.; BIASI, L. A.; COELHO, S. S. Extrato de alho na superação da dormência de pereira 'Housui'. Scientia Agraria, Curitiba, v.10, n.4, p.283-288, 2009.

https://doi.org/10.5380/rsa.v10i4.14772 
PENSO, G. A. Interação genótipo-ambiente na densidade de gemas e comprimento de ramos de pessegueiro. 107 P. Dissertação (Mestrado em Agronomia - Produção Vegetal). Universidade Tecnológica Federal do Paraná, Pato Branco, 2016. https://doi.org/10.21475/ajcs.18.12.03.pne744

PEREIRA, F. M.; MAYER, N. A. Fenologia e produção de gemas em cultivares e seleções de pessegueiro na região de Jaboticabal - SP. Revista Brasileira de Fruticultura. Jaboticabal - SP, v.30, n.1, p.043-047, 2008. https://doi.org/10.1590/s0100-29452008000100010

PETRI, J.L. Alternativas para quebra de dormência em fruteiras de clima temperado. In: ENCONTRO NACIONAL SOBRE FRUTICULTURA DE CLIMA TEMPERADO, 8., 2005, Fraiburgo. Anais... Caçador: Epagri, 2005. v.1, p.125-133. https://doi.org/10.1590/s0100-29452012000300037

RAIJ, B. van.; CANTARELLA, H.; QUAGGIO, J. A.; FURLANI, A. M. C. (Ed). Recomendações de adubações e calagem para o Estado de São Paulo. 2. Ed. Campinas: Instituto Agronômico, 1996. P. 137. (Boletim Técnico, 100). https://doi.org/10.1590/s0006-87051941000100001

RASEIRA, A.; PEREIRA, J.F.M.; MEDEIROS, A.R.M.; CARVALHO, F.L.C. Instalação e manejo do pomar. In: MEDEIROS, C.A.B.; RASEIRA, M. do C.B. A cultura do pessegueiro. Brasília: Embrapa SPI; Pelotas: Embrapa CPACT, 1998. p.130-160.

SCARIOTTO, S.; CITADIN, I.; RASEIRA, M. C. B.; SACHET, M. R.; PENSO, G. A. Adaptability and stability of 34 peach genotypes for leafing under Brazilian subtropical conditions. Scientia Horticulturae, v. 155, p. 111 - 117, 2013. https://doi.org/10.1016/j.scienta.2013.03.019

SEGANTINI, D. M.; LEONEL, S.; SILVA, A. C. C.; FERRAZ, R. A.; RIPARDO, A. K. S. Agronomic Performance of Peach Trees Grown in Subtropical Region. American Journal of Plant Sciences, v. 05, p. 3594-3602, 2014. https://doi.org/10.4236/ajps.2014.524375

SEGANTINI, D. M.; LEONEL, S.; SILVA RIPARDO, A. K.; TECCHIO, M. A.; DE SOUZA, M. E. Breaking Dormancy of -Tupy- Blackberry in Subtropical Conditions. American Journal of Plant Sciences, v. 06, p. 1760-1767, 2015. https://doi.org/10.4236/ajps.2015.611176

TASSONI, A.; FRANCESCHETTI, M.; BAGNI, N. Polyamines and salt stress response and tolerance in Arabidopsis thaliana flowers. Plant Physiology and Biochemistry, v. 46, p. 607-613, 2008. https://doi.org/10.1016/j.plaphy.2008.02.005

VALAGRO. Erger: o disjuntor de gemas. Atessa, 2010. Disponivel em: <http://www.valagro.com/ru/farm/products/valagro/specialties/erger?func=viewThingData;thingId=_uYISX0G Srv3tQuGmJdHSQ;thingDataId=lz44gK_jBr3_g90qWieu Mw>. Acesso em: 26 set. 2017.

WAGNER JÚNIOR, A.; BRUCKNER, C. H.; SALOMÃO, L. C. C.; PIMENTEL, L. D.; SILVA, J. O. C.; SANTOS, C. E. M. Seleção de Genótipos de Pessegueiro F1 com Baixa Necessidade de Frio Hibernal. Revista Brasileira de Fruticultura, Jaboticabal - SP, v. 31, n. 4, p. 1122-1128, Dezembro 2009. https://doi.org/10.1590/s0100-29452009000400028 